УДК 533.9.07+615.847

DOI: https://doi.org/10.26642/tn-2018-1(81)-69-73
R.O. Kolomiiets, Ph.D. T.M. Nikitchuk, Ph.D.

D.S. Morozov

O.V. Hrek

Zhytomyr State Technological University

\title{
Application of cold atmospheric plasma for the sterilization of objects of complex form
}

Poor healing wounds are a rather difficult problem for doctors, since they complicate even the most successful treatment. For example, in diabetes mellitus wounds arise due to injured vascular disease, with oncology and HIV - due to suppressed immunity, and in the elderly the reason is the low rate of cell division. The treatment of such wounds by the usual methods is very problematic, and sometimes it is simply impossible. It is also complicated because of the fact that such wounds usually have large sizes and complicated forms. It is possible to solve these problems with the help of low-temperature plasma.

The article considers the possibilities of using a cold plasma stream, its sterilizing and disinfecting properties. There are a lot of methods of sterilization and disinfection available in the world. The use of solutions of chemical agents, boiling, ionizing radiation, dryers, gas sterilizers have their advantages and disadvantages. Cold plasma can be used not only for therapeutic influences, but also for the treatment of tools and materials for the treatment of intradermal infection. The structure of the construction, which allows to increase the area of treatment with cold plasma jets, is proposed. The possibility of processing difficult-to-reach areas and objects of complex form is considered.

In the conclusion, an analysis was made of the use of the design of a multi-stream creep plasma generator for therapeutic effects and to achieve antibacterial effects.

Keywords: cold plasma; multi-jet cold plasma generator; pin-to-hole discharge.

1. Introduction. The modern period of development of medicine is characterized by an increase in the number of surgical infections and postoperative purulent-inflammatory complications. It is based on general biological reasons, which are based on changes in the immunological resistance of the human body, as well as the causes associated with technical progress. The possibility of invasion of chronic infectious agents is increasing due to the increase in traumatism, the volume and duration of surgical interventions, as well as the wide use of various technical means of synthetic implants, metal constructions, intravascular catheters, etc. Sterilization and treatment of open wounds, burns of complex form, as well as surgical instruments and various constructions can be performed using a stream of cold plasma jets.

Cold plasma has a wide range of applications due to its ability to control its physical and chemical parameters. Numerous experiments in vivo and in vitro show that low-temperature atmospheric plasma has a valuable health impact with high potential applications: antibacterial, fungicidal and antiviral; disinfection of tissues [1-3], treatment of wounds and burns [4-6], therapy in oncology and dermatology [7-9], sterilization of different surfaces and food [10-13], etc. Various plasma parameters such as a mix of ions / electrons, their spatial and energy distributions, temperature, power, light radiation spectrum, jet shape and environmental conditions affect the convenience and the ability of its use. For example, a jet with a uniform distribution of plasma parameters on the treated site should be created to achieve a uniform sterilizing effect. In order to achieve widespread use of cold plasma in medicine, it is first necessary to solve the problem of increasing the plasma treatment area. This will allow to process uneven, and sometimes liquid surfaces (deep open wounds, food, water, complex surgical instruments). Such small sizes allow the use of plasma in localized areas, such as cell processing [14] and dentistry [15-17]. This possibility is not best realized by separate reactive sources of cold plasma, in diameter from a few millimeters or less. Large sources of cold plasma generation in tens of centimeters are needed to solve this problem.

2. Peculiarities of the cold plasma use. A large number of experiments prove that the cold (nonequilibrium) plasma has rather valuable properties with a high potential medicine use i.e. bactericidal and antiviral action, and also affects blood coagulation, the immune system, cancer cells. The interest of modern medicine in the use of generators of cold atmospheric plasma is resulted in their relative simplicity and high efficiency. The use of such generators in developed countries began about ten years ago and is now becoming more widespread.

Cold plasma kills bacteria better than antibiotics $[18,19]$. When treating wounds with cold plasma, a wide range of nutrients (NO, O3, OH-, O2-, H2O2, UV-radiation), that destroy pathogenic microorganisms and toxic substances that are products of their life, are created. It has now been clinically proven that cold plasma is an effective means of inactivating microorganisms, so it is used to disinfect wounds and sterilize medical instruments. 
A very large overview of the medical applications of cold plasma is given in [20], and the bibliography (which mainly refers to medical articles about the results of cold plasma therapy) has more than 300 titles. Clinics of Western Europe (first of all Germany, Italy and France) and the USA are the main consumers of therapeutic devices using cold plasma. The variety of areas of cold plasma use in medicine determines the need for various constructive solutions for cold plasma generators. The «universal» plasma generator cannot be, but there is and will always be necessary for highly specialized plasma equipment [21].

3. Classification of types of cold plasma generators. With all the variety of devices for cold-plasma therapy, there are relatively few types of cold plasma generators. By the type of gas used, the sources of cold atmospheric, helium, and argon plasma were most widely used. The sources of atmospheric plasma are of greatest interest precisely as the most universal. Their main advantage is the lack of the need in a gas cylinder (balloon) and the ability to produce plasma directly from the air.

Depending on the design of the "igniter" part of the cold plasma generators, five main types of structures can be identified:

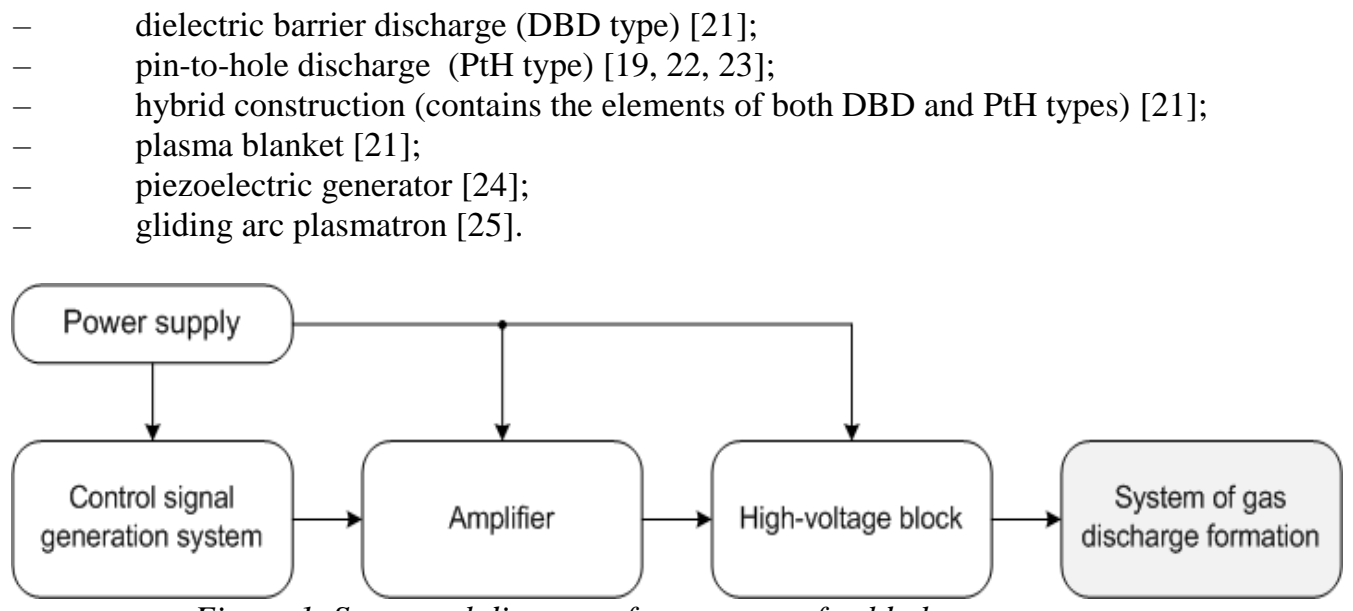

Figure 1. Structural diagram of most types of cold plasma generators

With the exception of the piezoelectric cold plasma generator, the principle of operation of all other types can be described using the structural diagram shown in the Figure 1. The control signal from the system of its formation goes to the amplifier, and the signal amplified by power is fed to the high-voltage block. The system of gas discharge formation with the help of the corresponding electrodes generates either a plasma jet (PtH type) or a discharge distributed over the area (DBD type or plasma blanket). A power supply is required to operate the entire system. The blocks indicated in the diagram in white color are electronic blocks without any mechanical features, and the gas discharge formation system (denoted by gray color) is a mechanical system of electrodes.

A separate type of cold plasma generators should be allocated to multi-jet devices [26]. They are built on the basis of cold plasma generators of the type PTM, which are recruited in a row or matrix.

4. Multi-jet CP-generator for processing objects of complex shape. This paper studies the idea of a new installation for creating a flow of low-temperature atmospheric plasma with a multi-flow zone of discharge, which provides a wide area of homogeneity of the main characteristics of the plasma.

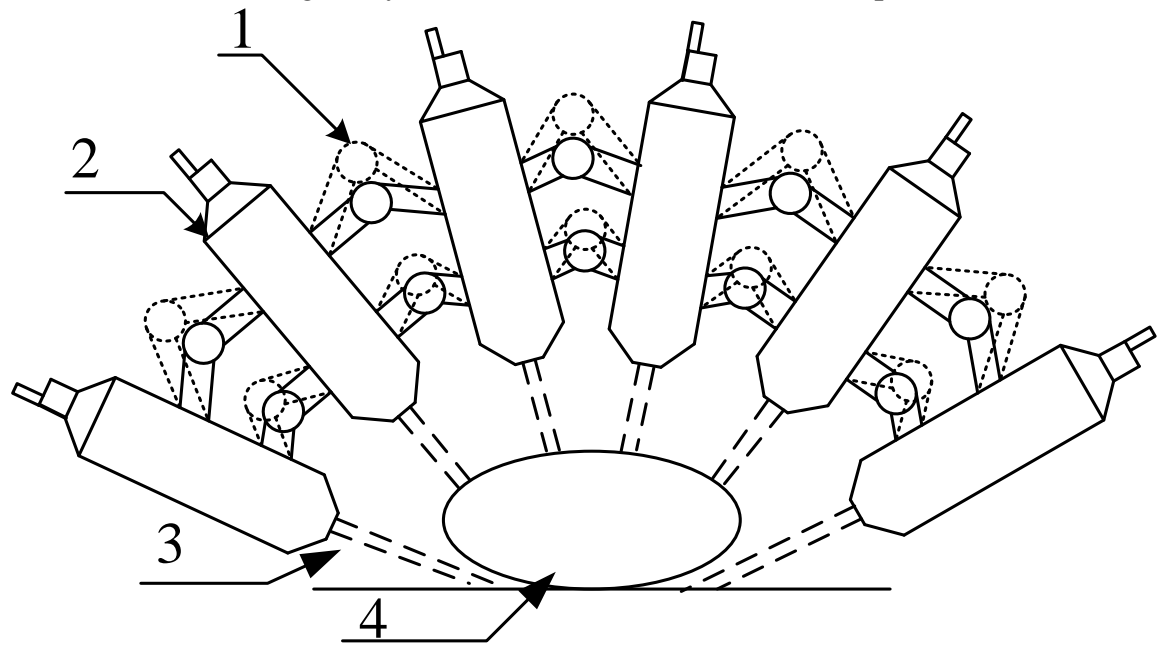

Figure 2. Multi-jet cold plasma generator for processing objects of complex shape 
Figure 2 depicts the scheme of construction of a multifunctional system of cold-plasma processing of complex shape samples, where:

1 - hinges that change the shape of the structure;

2 - cold plasma generator device, which works on a pin-to-hole type of discharge;

3 - plasma jet;

4 - the object that is being processed.

The number of generators can vary from one to seven and more. In cold plasma generators operating on a pin-to-hole type, high voltage pulses are fed to electrodes protected by a dielectric cylindrical housing. One of the electrodes is a ring, and the other is made in the form of a probe along the central longitudinal axis of the cylinder. An inert gas or air is pumped into the cylinder under low pressure. The gas is ionized when it passes between the electrodes and the resulting plasma goes outside under pressure.

One of the very promising options for generators of cold plasma for this application is the design described in [27]. Its main advantage is that in such a design the plasma is formed directly near the nozzle, which substantially reduces the loss of the degree of ionization of the gas before it comes into contact with the object being processed.

5. Conclusion. The structure of the multi-jets unit for the processing of objects of complex form is proposed. The advantages of this installation are flexibility, change in design size. The number of jets can be changed from two to seven. It provides mounting with moving hinges. These same hinges make it possible to change the direction of plasma jets. Such advantages of the design allow to handle various complex wounds, when the patient is immovable, to sterilize surgical instruments, implants, etc., to disinfect various solutions.

\section{References:}

1. Sterilization mechanism for Escherichia coli by plasma flow at atmospheric pressure / T.Sato, T.Miyahara, A.Doi, S.Ochiai // Appl. Phys. Lett. - 2006. - Vol. 89, No. 073902 [On-line]. - Access mode : https://doi.org/10.1063/1.2336594.

2. Effects of cell surface loading and phase of growth in cold atmospheric gas plasma inactivation of Escherichia coli K12 / H.Yu, S.Perni, J.J. Shi, D.Z. Wang, M.G. Kong, G.Shama // J. Appl. Microbiol. - 2006. - Vol. 101 (6). Pp. 1323-1330.

3. Inactivation of Bacteria by the Plasma Pencil / M.Laroussi, C.Tendero, X.Lu, S.Alla, W.L. Haynes // Plasma Process. Polym. - 2006. - Vol. 3. - P. 470 [On-line]. - Access mode : https://doi.org/10.1002/ppap.200600005.

4. Plasma medicine: an introductory review / M.G. Kong, G.Kroesen, G.Morfill, T.Nosenko, T.Shimizu, J. van Dijk, J.L. Zimmermann // New Journal of Physics. - 2006. - Vol. 11.

5. Low-temperature plasmas at atmospheric pressure: toward new pharmaceutical treatments in medicine / M.Yousfi, N.Merbahi, A.Pathak, O.Eichwald // Fundamental and Clinical Pharmacoldgy. - 2014. - Vol. 28. - P.p. 123-135.

6. Morfill G.E. The Munich plasma medicine project: results and current status 2nd Int. / G.E. Morfill // Conf. Plasma Medicine. - San Antonio, TX, USA. - 16-20 March, 2009.

7. Floating electrode dielectric barrier discharge plasma in air promoting apoptotic behavior in melanoma skin cancer cell lines / G.Fridman, A.Shereshevsky, M.M. Jost, A.D. Brooks, A.Fridman, A.Gutsol, V.Vasilets, G.Friedman // Plasma Chemestry and Plasma Processing. -2007. - Vol. 27. - Pp. 163-176.

8. Air plasma coupled with antibody-conjugated nanoparticles: a new weapon against cancer / G.C. Kim, G.J. Kim, S.R. Park, S.M. Jeon, S.J. Seo, F.Iza, J.K. Lee // Journal of Physics D: Applied Physics. - 2009. - Vol. 42, No. 3.

9. Degradation of adhesion molecules of G361 melanoma cells by a non-thermal atmospheric pressure microplasma / H.J. Lee, C.H. Shon, Y.S. Kim, S.Kim, G.C. Kim, M.G. Kong // New Journal of Physics. - 2009. - Vol. 11, No. 115026.

10. Inactivation of Escherichia coli on almonds using nonthermal plasma / S.Deng, R.Ruan, C.K. Mok, G.Huang, X.Lin, P.Chen // J. Food Sci. - 2007. - Vol. 72, No. 62.

11. Cold atmospheric plasma decontamination of the pericarps of fruit / S.Perni, D.W. Liu, G.Shama, M.G. Kong // Journal of food protection. - 2008. - Vol. 71 (2). - Pp. 302-308.

12. Perni S. Cold atmospheric plasma disinfection of cut fruit surfaces contaminated with migrating microorganisms / S.Perni, G.Shama, M.G. Kong // Journal of food protection. - 2008. - Vol. 71 (8). - Pp. 1619-1625.

13. Selcuk M. Decontamination of grains and legumes infected with Aspergillus spp. and Penicillum spp. by cold plasma treatment / M.Selcuk, L.Oksuz, P.Basaran // Bioresour Technology. - 2008. - Vol. 99 (11). - Pp. 5104-5109.

14. Leveille $V$. Design and preliminary characterization of a miniature pulsed RF APGD torch with downstream injection of the source of reactive species / V.Leveille, S.Coulombe // Plasma Sources Science and Technology. - 2005. - Vol. 14. Pp. 467-476.

15. An RC Plasma Device for Sterilization of Root Canal of Teeth / X.P. Lu., Y.G. Cao, P.Yang., Q.Xiong, Z.L. Xiong, Y.B. Xian, Y.Pan // IEEE Transactions on Plasma Science. - 2009. - Vol. 37. - Pp. 668-673.

16. Tooth bleaching with nonthermal atmospheric pressure plasma / H.W. Lee., G.J. Kim., J.M. Kim, J.K. Park, J.K. Lee, G.C. Kim // Journal of endodontics. - 2009. - Vol. 35 (4). - Pp. 587-591.

17. Pulsed Atmospheric-Pressure Cold Plasma for Endodontic Disinfection / C.Jiang, M.T. Chen, C.Schaudinn, A.Gorur, P.T. Vernier, J.W. Costerton, D.E. Jaramillo, P.P. Sedghizadeh, M.A. Gundersen // IEEE Transactions on Plasma Science. - 2009. - Vol. 37. - Pp. 1190-1195.

18. Laroussi M. Low-temperature plasma in medicine / M.Laroussi // IEEE Transactions of Plasma Sciences. - 2009. Vol. 37, No. 6. - Pp. 714-725. 
19. Applied plasma medicine / G.Fridman, G.Friedman, A.Gutsol, A.Shekhter, V.Vasilets, A.Fridman / Plasma Processes and Polymers. - 2008. - No. 5. - Pp. 503-533.

20. Han J. Review of major directions in non-equilibrium atmospheric plasma treatments in medical, biological, and bioengineering applications / J.Han // Plasma Medicine. - 2003. - No. 3 (3). - Pp. 173-242.

21. Cold atmospheric plasma devices for medical issues / G.Isbary, T.Shimizu, Y.-F. Li, W.Stolz., H.M. Thomas, G.E. Morfill, J.L. Zimmermann // Expert Rev. Med. Device. - 2013. - No. 10 (3). - Pp. 367-377.

22. Cold Plasma Sterilization of Open Wounds: Live Rat Model / D.Dobrynin, K.Wasko, G.Friedman, A.Fridman, G.Fridman // Plasma Medicine. - 2011. - No. 1, 2. - Pp. 109-114.

23. Cold Atmospheric Plasma in Cancer Therapy / M.Keidar, A.Shashurin, O.Volotskova, M.A. Stepp, P.Srinivasan, A.Sandler, B.Trink // Physics of Plasmas. - 2013. - Vol. 20, No. 5, 057101 [On-line]. DOI : 10.1063/1.4801516.

24. Operating Instruction for piezobrush ${ }^{\circledR}$ PZ2 handheld device. - 2013. - [On-line]. - Access mode : https://www.relyon-plasma.com/wp-content/uploads/2016/05/piezobrush-pz2-plasma-handheld-manualMLLF0351300.pdf.

25. Plasma acid production in a gliding arc plasmatron / R.D. Robinson, K.Gutsol, A.Rabinovich, A.Fridman // Plasma Medicine. - 2012. - Vol. 2 (4). - Pp. 249-258.

26. Multijet atmospheric plasma device for biomedical application / V.Zablotskii, O.Churpita, Z.Hubička, L.Jastabrik, A.Dejneka // Plasma medicine. - 2011. - No. 2. - Pp. 135-141.

27. Kolomiiets R. Cold plasma generator for medical use / R.Kolomiiets // Plasma Medicine. - 2017. - Vol. 7 (1). Pp. 1-6.

\section{References:}

1. Sato, T., Miyahara, T., Doi, A. and Ochiai, S. (2006), «Sterilization mechanism for Escherichia coli by plasma flow at atmospheric pressure», Appl. Phys. Lett., Vol. 89, No. 073902, [On-line], available at: https://doi.org/10.1063/1.2336594

2. Yu, H., Perni, S., Shi, J.J., Wang, D.Z., Kong, M.G. and Shama, G. (2006), «Effects of cell surface loading and phase of growth in cold atmospheric gas plasma inactivation of Escherichia coli K12», J. Appl. Microbiol., Vol. 101 (6), pp. 1323-1330.

3. Laroussi, M., Tendero, C., Lu, X., Alla, S. and Haynes, W.L. (2006), «Inactivation of Bacteria by the Plasma Pencil», Plasma Process. Polym., Vol. 3, P. 470, [On-line], available at: https://doi.org/10.1002/ppap.200600005

4. Kong, M.G., Kroesen, G., Morfill, G., Nosenko, T., Shimizu, T., Dijk, van J. and Zimmermann, L. (2009), «Plasma medicine: an introductory review», New Journal of Physics, Vol. 11.

5. Yousfi, M., Merbahi, N., Pathak, A. and Eichwald, O. (2014), «Low-temperature plasmas at atmospheric pressure: toward new pharmaceutical treatments in medicine», Fundamental and Clinical Pharmacoldgy, Vol. 28, p.p. 123-135.

6. Morfill, G.E. (2009), «The Munich plasma medicine project: results and current status 2nd Int.», Conf. Plasma Medicine, from 16-20 March, San Antonio, TX, USA.

7. Fridman, G., Shereshevsky, A., Jost, M.M., Brooks, A.D., Fridman, A., Gutsol, A., Vasilets, V. and Friedman, G. (2007), «Floating electrode dielectric barrier discharge plasma in air promoting apoptotic behavior in melanoma skin cancer cell lines», Plasma Chemestry and Plasma Processing, Vol. 27, pp. 163-176.

8. Kim, G.C., Kim, G.J., Park, S.R., Jeon, S.M., Seo, S.J., Iza, F. and Lee, J.K. (2009), «Air plasma coupled with antibody-conjugated nanoparticles: a new weapon against cancer», Journal of Physics D: Applied Physics, Vol. 42, No. 3.

9. Lee, H.J., Shon, C.H., Kim, Y.S., Kim, S., Kim, G.C. and Kong, M.G. (2009), «Degradation of adhesion molecules of G361 melanoma cells by a non-thermal atmospheric pressure microplasma», New Journal of Physics, Vol. 11, No. 115026.

10. Deng, S., Ruan, R., Mok, C.K., Huang, G., Lin, X. and Chen, P. (2007), «Inactivation of Escherichia coli on almonds using nonthermal plasma», J. Food Sci., Vol. 72, No. 62.

11. Perni, S., Liu, D.W., Shama, G. and Kong, M.G. (2008), «Cold atmospheric plasma decontamination of the pericarps of fruit», Journal of food protection, Vol. 71 (2), pp. 302-308.

12. Perni, S., Shama, G. and Kong, M.G. (2008), «Cold atmospheric plasma disinfection of cut fruit surfaces contaminated with migrating microorganisms», Journal of food protection, Vol. 71 (8), pp. 1619-1625.

13. Selcuk, M., Oksuz, L. and Basaran, P. (2008), «Decontamination of grains and legumes infected with Aspergillus spp. and Penicillum spp. by cold plasma treatment», Bioresour Technology, Vol. 99 (11), pp. 5104-5109.

14. Leveille, V. and Coulombe, S. (2005), «Design and preliminary characterization of a miniature pulsed RF APGD torch with downstream injection of the source of reactive species», Plasma Sources Science and Technology, Vol. 14, pp. 467-476.

15. Lu, X.P., Cao, Y.G., Yang, P., Xiong, Q., Xiong, Z.L., Xian, Y.B. and Pan, Y. (2009), «An RC Plasma Device for Sterilization of Root Canal of Teeth», IEEE Transactions on Plasma Science, Vol. 37, pp. 668-673.

16. Lee, H.W., Kim, G.J., Kim, J.M., Park, J.K., Lee, J.K. and Kim, G.C. (2009), «Tooth bleaching with nonthermal atmospheric pressure plasma», Journal of endodontics, Vol. 35 (4), pp. 587-591.

17. Jiang, C., Chen, M.T., Schaudinn, C., Gorur, A., Vernier, P.T., Costerton, J.W., Jaramillo, D.E., Sedghizadeh, P.P. and Gundersen, M.A. (2009), «Pulsed Atmospheric-Pressure Cold Plasma for Endodontic Disinfection», IEEE Transactions on Plasma Science, Vol. 37, pp. 1190-1195.

18. Laroussi, M. (2009), «Low-temperature plasma in medicine», IEEE Transactions of Plasma Sciences, Vol. 37, No. 6, pp. 714-725.

19. Fridman, G., Friedman, G., Gutsol, A., Shekhter, A., Vasilets, V. and Fridman, A. (2008), «Applied plasma medicine», Plasma Processes and Polymers, No. 5, pp. 503-533. 
20. Han, J. (2013), «Review of major directions in non-equilibrium atmospheric plasma treatments in medical, biological, and bioengineering applications», Plasma Medicine, No. 3 (3), pp. 173-242.

21. Isbary, G., Shimizu, T., Li, Y.-F., Stolz, W., Thomas, H.M., Morfill, G.E. and Zimmermann, J.L. (2013), «Cold atmospheric plasma devices for medical issues», Expert Rev. Med. Device, No. 10 (3), pp. 367-377.

22. Dobrynin, D., Wasko, K., Friedman, G., Fridman, A., Fridman, G. (2011), «Cold Plasma Sterilization of Open Wounds: Live Rat Model», Plasma Medicine, No. 1, No. 2, pp. 109-114.

23. Keidar, M., Shashurin, A., Volotskova, O., Stepp, M.A., Srinivasan, P., Sandler, A., Trink, B. (2013), «Cold Atmospheric Plasma in Cancer Therapy», Physics of Plasmas, Vol. 20, No. 5, 057101, [On-line], available at: DOI: $10.1063 / 1.4801516$

24. www.relyon-plasma.com (2013), «Operating Instruction for piezobrush ${ }^{\circledR}$ PZ2 handheld device», available at: https://www.relyon-plasma.com/wp-content/uploads/2016/05/piezobrush-pz2-plasma-handheld-manualML\F0351300.pdf

25. Robinson, R.D., Gutsol, K., Rabinovich, A. and Fridman, A. (2012), «Plasma acid production in a gliding arc plasmatron», Plasma Medicine, Vol. 2 (4), pp. 249-258.

26. Zablotskii, V., Churpita, O., Hubička, Z., Jastabrík, L. and Dejneka, A. (2011), «Multijet atmospheric plasma device for biomedical application», Plasma medicine, No. 2, pp. 135-141.

27. Kolomiiets, R. (2017), «Cold plasma generator for medical use», Plasma Medicine, Vol. 7 (1), pp. 1-6.

Коломієць Роман Олександрович - кандидат технічних наук, старший викладач кафедри біомедичної інженерії та телекомунікацій Житомирського державного технологічного університету.

Наукові інтереси:

- застосування холодної плазми у медицині;

- фізика і техніка високих напруг;

- фізика живого.

E-mail: r.o.kolomiiets@gmail.com; krt_kro@ztu.edu.ua.

Нікітчук Тетяна Миколаївна - кандидат технічних наук, доцент кафедри біомедичної інженерії та телекомунікацій Житомирського державного технологічного університету.

Наукові інтереси:

- біофізика серцево-судинної системи;

- моделювання та методи обробки пульсових хвиль;

- застосування холодної плазми у медицині.

E-mail: tnikitchuk@ukr.net.

Морозов Дмитро Сергійович - старший викладач кафедри біомедичної інженерії та телекомунікацій Житомирського державного технологічного університету.

Наукові інтереси:

- НВЧ-методи дослідження складу речовини;

- об'ємні резонатори;

- генератори холодної плазми.

E-mail: morozovds@ztu.edu.ua.

Грек Олександра Вікторівна - аспірант кафедри біомедичної інженерії та телекомунікацій Житомирського державного технологічного університету.

Наукові інтереси:

- холодна плазма;

- газовий розряд;

- $\quad$ коагуляція холодною плазмою.

E-mail: sashagrek@ukr.net.

Article was received by the editorial staff 18.05.2018. 